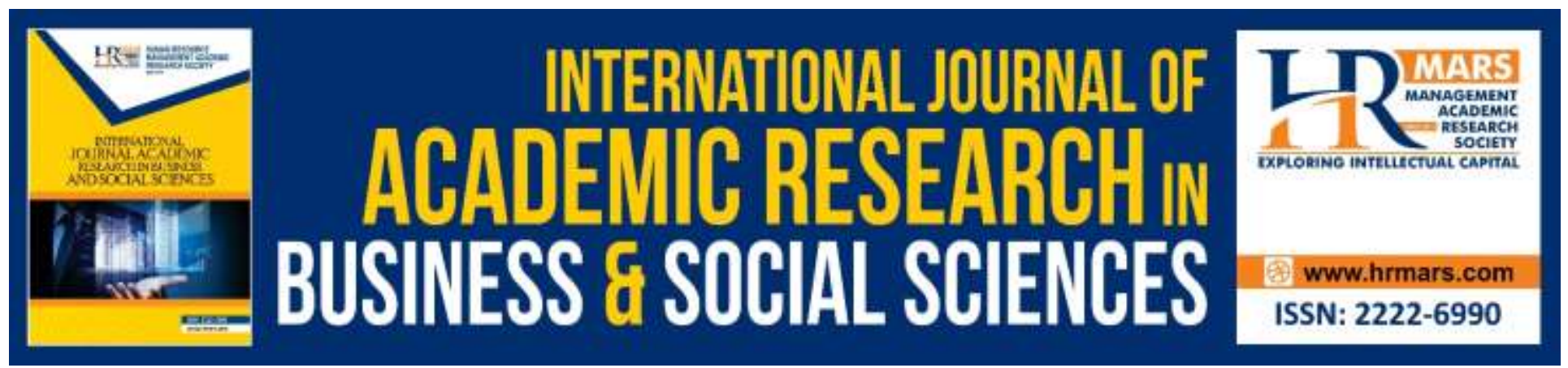

\title{
The Multifaceted of Themed Restaurant: Exploring the Unique and Vulnerable Elements in Staging Authentic Dining Experience
}

Ishak, F. A. C., Zainun, N. A. A, Karim, M. S., Ungku Zainal Abidin, U. F., and Mohamad, S. F.

To Link this Article: http://dx.doi.org/10.6007/IJARBSS/v10-i3/7097

DOI:10.6007/IJARBSS/v10-i3/7097

Received: 02 February 2020, Revised: 23 February 2020, Accepted: 12 March 2020

Published Online: 29 March 2020

In-Text Citation: (Ishak et al., 2020)

To Cite this Article: Ishak, F. A. C., Zainun, N. A. A., Karim, M. S., Ungku Zainal Abidin, U. F., \& Mohamad, S. F. (2020). The Multifaceted of Themed Restaurant: Exploring the Unique and Vulnerable Elements in Staging Authentic Dining Experience. International Journal of Academic Research in Business and Social Sciences, 10(3), 855-868.

\section{Copyright: (c) 2020 The Author(s)}

Published by Human Resource Management Academic Research Society (www.hrmars.com)

This article is published under the Creative Commons Attribution (CC BY 4.0) license. Anyone may reproduce, distribute, translate and create derivative works of this article (for both commercial and non-commercial purposes), subject to full attribution to the original publication and authors. The full terms of this license may be seen at: http://creativecommons.org/licences/by/4.0/legalcode

\section{Vol. 10, No. 3, 2020, Pg. 855 - 868}

Full Terms \& Conditions of access and use can be found at http://hrmars.com/index.php/pages/detail/publication-ethics 


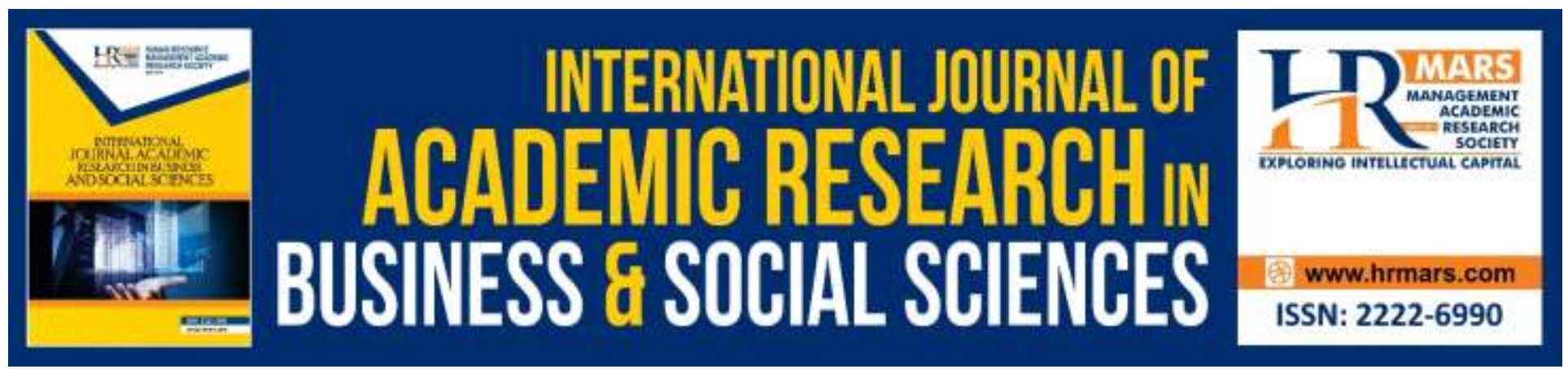

\title{
The Multifaceted of Themed Restaurant: Exploring the Unique and Vulnerable Elements in Staging Authentic Dining Experience
}

\author{
Ishak, F. A. C., Zainun, N. A. A, Karim, M. S., Ungku Zainal Abidin, \\ U. F., and Mohamad, S. F.
}

Department of Food Service and Management, Faculty of Food Science and Technology, Universiti Putra Malaysia, 43400, Serdang, Selangor, Malaysia

Email: farahadibah@upm.edu.my

\begin{abstract}
The diversity of foodservice establishments in the market not only extending the menu options but also offering a wider range of dining experiences. In particular, dining at a themed restaurant is viewed as an authentic, fun and pleasurable experience. However, a small glitch from the management may turn down the whole dining experience. Thus, the objective of this research is twofold; to identify the uniqueness of the themed restaurant in delivering the authentic dining experience, and to explore the weaknesses leading to the poor dining experience. Through qualitative research, this study has interviewed a number of customers who experienced dining in various themed restaurants across Klang Valley area. Semi-structured interviews had been carried out in the process to assist the researcher in getting a deeper understanding of experience consumption. Participant observation was also executed through field visits to the selected restaurants to get the first-hand experience. Based on the results, it showed that customers enjoyed the dining moments because of the aesthetic facility, comforting ambiance, and attentive service staff. In contrast, including inadequate restaurant maintenance, the contradiction of expectation with reality in food presentation and pricy menu items contribute to poor dining experience. The contributing factors to these experiences were discovered hence filled the gap of previous studies and offer the future researchers a deeper understanding of the themed restaurant's forte. Practically, the findings can help the existing and new restaurateurs to improve their offerings in staging a unique dining experience that satisfies the customers' needs and wants.
\end{abstract}

Keywords: Themed Restaurant, Authentic Dining, Unique, Weakness, Consumption Journey

Introduction

The dining experience in a themed restaurant is not merely a casual dining momento. As explained by Heung and $\mathrm{Gu}$ (2012), dining is not only the taste of the food but also the effects of the 
INTERNATIONAL JOURNAL OF ACADEMIC RESEARCH IN BUSINESS AND SOCIAL SCIENCES Vol. 10, No. 3, March, 2020, E-ISSN: 2222-6990 @ 2020 HRMARS

atmosphere on the customer. Previous studies addressed that authenticity is essential in producing positive emotions to the customer (Chang, 2016). Therefore, the authenticity of the chosen themed should be well delivered not only through food but also the environment to create a memorable dining experience.

In particular, the works by King (1998) and Kim (2015) emphasized that human being focuses to maintain the level of well-being and improve the quality of life. Therefore, they are looking for products and services that will not only meet their needs but also satisfy their wants. In the context of a restaurant, customers are looking for unique types of theming and an upscale restaurant to gain new experience and give pleasure to their life. Concerning these aims, many restaurants distinguish themselves to meet customers' preferences through particular theming which defining and specifying its servicescapes (Mehrabian and Russell, 1974; Wood and Munoz, 2007; Ryu and Jang, 2008) to attract customer. Based on Dong and Siu (2013) and Tsai and Lu (2012), theming is an effective strategy to differentiate themed restaurants from competitors. This is because the overall ambiance in themed restaurants usually take customers into a specific theme and create a sense of "travel" to the exotic or unique experiences (Wood and Munoz, 2006).

As themed restaurant is known with its theming atmosphere and servicescape, Ryu and Jang (2008) has proposed the term "DINESCAPE" that is the man-made physical and human surroundings of an upscale restaurant but restricted to the inside of the dining area and exclude the exterior environment such as the parking area or the building design. Ishak, Crang and Karim (2017) have come out with more specific elements to stage a better dining experience specifically in themed restaurants such as lighting, color, music, spatial layout, scents and props. Staging an ambiance with the specific theme as the anchor, themed restaurant able to stage and offer authentic dining experience to its patrons. As authenticity is referred to the quality of being original, real or true (Taylor, 1991), the authentic dining experience is the level to which the food and dining environment are perceived as original to its type and reflect the concept or themed chosen (Liu, 2018). Themed restaurant can deliver this.

However, to acquire a strong impression from the customers, restaurateurs are struggling to create or staged the best environment and ambiance in favor of memorable dining. This is parallel with the previous study which found that even the food and service are in high quality, the customers will not be happy if the physical environment is not pleasurable (Hwang and Ok, 2013). Other than the defects in the physical environment, it is also difficult for restaurateurs to satisfy every customers' desire due to the subjective individual preferences and other contributing factors. Walter and Edvardsson (2012) claimed that there is a list of elements involved in the customer service experience process that leads to either favorable or unfavorable experiences. Some customers might have an enjoyable dining experience while others might find it unpleasable even they dine at the same restaurant (Ishak, Crang and Karim, 2017).

Therefore, most restaurateurs today are decorating their restaurants with a particular theme in order to offer a distinguished dining experience to the customers. Some restaurants move beyond the miles by including the element of surprise upon customers' arrival to give an unexpected moment and something to be remembered (Walter and Edvardsson, 2012). A themed restaurant that manages to deliver authentic dining will satisfy the customers and perhaps leading to a higher chance of revisit intention from them. Customers are also willing to pay more if they consume not only good food but also an exclusive experience throughout their visit to the restaurant. 
INTERNATIONAL JOURNAL OF ACADEMIC RESEARCH IN BUSINESS AND SOCIAL SCIENCES Vol. 10, No. 3, March, 2020, E-ISSN: 2222-6990 @ 2020 HRMARS

However, literature documented fewer studies on dining experience from the customers' perspective. How far do the attributions of the themed restaurant provide the authenticity in a dining experience to the customer and how much do they enjoy the dining process also remains unknown. Besides that, a small number of studies that use different methodologies such as observations and photo-based methods to deepen the evidence of the findings and illustrate the real environment as claimed by Walter and Edvardsson (2012). In addition, based on the research by Tsai and Lu (2012), they suggested future researchers to conduct qualitative design studies to explore the authentic dining experience, after a series of studies carried out quantitatively. Hence, the aim of this study is twofold; to identify the uniqueness of a themed restaurant in delivering the authentic dining experience, and to explore the weaknesses of themed restaurant which contribute to the poor dining experience.

\section{Literature Review}

Themed restaurant begins to get the spotlight when customers started to demand not only for good foods but also an upright ambiance during the dining process inside the restaurant. Themed restaurant is defined as the eating place that highlighted a particular theme and decorated with a variety of distinctive signs unrelated to eating itself (Beardsworth and Bryman, 1999). For example, a cowboy themed restaurant is elaborated through its décor related to cowboys such as hats, shotguns, leather boots and horses' pictures, which is very contrasted to an ordinary casual restaurant ambiance. This kind of environment will give a unique dining experience to the customer because of the effects of servicescape in the restaurant and authentic experiences offered (Tsai and Lu, 2012).

Historically, Whitaker (2010) claimed that the first themed restaurant begun in the later nineteenth century which is Paris café in Montmartre called "The Cabaret of Nothingness" which emphasized a supernatural theming. Later in 1885, Café du Bagne (Café of the Penitentiary) established in 1885 by Maxime Lisbonne was the café which the dining hall replicated a prison. Accentuating the theme, the waiters wore the real convict's attire with fake chains and cuffs. Besides that, there was also The L'Abbaye de Thélème with a gothic theme and the server dressed as monks and nuns. Upon the birth of these cafés, other themed-restaurants were inspired and rapidly evolved throughout the world.

Today, there are a variety of themed restaurants around the globe representing unique theming and can be an exciting and fun place to dine. The following Table 1 listed a few of themed restaurants in the world today.

\begin{tabular}{|c|c|c|}
\hline Restaurant & Theme & Location \\
\hline Godabang Cat Café & Cat & South Korea \\
\hline The Clinic & Hospital & Singapore \\
\hline Ninja New York & Ninja & New York \\
\hline The Jekyll and Hyde Club & Haunted & USA \\
\hline Rainforest Café & Rainforest & Taiwan \\
\hline Modern Toilet & Toilet & Lebanon \\
\hline Buns and Guns & Military & Spain \\
\hline The Disaster Café & Earthquake & . \\
\hline
\end{tabular}

Table 1: Among the themed restaurants around the world (Source: compiled by author) 
INTERNATIONAL JOURNAL OF ACADEMIC RESEARCH IN BUSINESS AND SOCIAL SCIENCES Vol. 10, No. 3, March, 2020, E-ISSN: 2222-6990 @ 2020 HRMARS

Previous studies highlighted that the consumption process in highlighted servicescapes and themed environment provide a memorable experience and give benefits such as fantasies, pleasure and fun (Han and Jeong, 2013; Hwang and Lyu, 2015). Thus, not to be left out, Malaysia also has a diversity of themed restaurants which characterized uniquely. The following table compiles a list of themed restaurants in Malaysia.

\begin{tabular}{|c|c|c|}
\hline Restaurant & Theme & Location \\
\hline The Shire Café & Lord of The Ring & Sri Petaling \\
\hline DC Comic Café & Superhero & Kuala Lumpur \\
\hline The Grumpy Cyclist & Bicycle & Kuala Lumpur \\
\hline Out of Africa \& Kudu Bar & Africa & Petaling Jaya \\
\hline The Teddy Restaurant & Teddy Bear & Kelana Jaya \\
\hline Old China Café & Baba Nyonya & Petaling Street \\
\hline $\begin{array}{c}\text { Denali and Pinnacles; The Wanderer's } \\
\text { Café }\end{array}$ & Bohemian & Bangi \\
\hline Ahoy Café & Pirate & Subang Jaya \\
\hline
\end{tabular}

Table 2 Among the themed restaurants in Malaysia (Source: compiled by author)

\section{Dining Experience Elements}

Experiencing dining in themed restaurant is not merely like a casual dining. As explained by Heung and Gu (2012), dining is not only the taste of the food but also the effects of the atmosphere on the customer. Based on the previous studies, authenticity is very important in producing positive emotions to the customer (Chang, 2016). Therefore, the authenticity of the chosen themed should be well delivered not only through food but also the environment to create a memorable dining experience.

In line with the notion, Ali, Kim and Ryu (2016) accentuate that the physical environment of an establishment does not have a unified description. The previous researchers identified various elements contributing to the dining experience and among them known as SERVICESCAPE and DINESCAPE. For instance, servicescape (Bitner, 1992) referred to the tangible and intangible elements such as ambient, layout, sign, symbols and artefacts. In further discussion, Ryu and Jang (2008) coined dinescape which put emphasizes on facility aesthetics, ambience, lighting, service product, layout, and social factors.

\section{Facility Aesthetic}

Facility aesthetic is the architectural design, interior design, and decorations that contribute to the attractiveness of the physical environment that attracts the customer in every way (Ilgaz, Berrin and Ceren, 2018). As pointed out by Hwang and Ok (2013), the physical environment of a restaurant can give a good first impression to the incoming customers. This idea is supported by Liu and Tse (2018) who found that customer satisfaction during the dining experience is depending on the atmospherics which are the physical and service environments. For example, the interior design such as the pictures on the wall and flowers or centerpieces on the table may help to increase the perceived authentic quality of the physical environment (Ryu, 2005). Walter and Edvardsson (2012) also agreed with the findings where they emphasized that the theme delivered and decorations 
displayed in the restaurant are essential to help the customer remember every detail of the environment when they leave the restaurant.

In addition, Ilgaz, Berrin and Ceren (2018) also focused on the exterior design such as the parking space and the availability of the restroom. The parking space is essential for restaurants which is isolated or located away from public place or public building like a shopping mall. Although some of the exteriors cannot be controlled, the location of the restaurant is indeed in the manager's or owner's hand and it should be taken into consideration during the planning phase. Other than that, the availability of the restroom inside the building or inside the restaurant may be one of the factors that are a convenience for the customer and can please them.

\section{Ambiance}

Ambiance refers to the less tangible or sensory and more 'background' element of the restaurant space, including temperature, noise, music and scent (Baker, 1987). According to Ishak, Crang and Karim (2017), music and lighting are among the commonly controllable elements of sonic and luminous ambiance of a restaurant. Music not only help in bringing out the senses (Ryu and Jang, 2008) and satisfy the customer (Namkung and Jang, 2008) but it also gives relaxation (Magnini and Parker, 2009). However, if the music is too loud it can inhibit conversation and if the music is too soft, it will fail to give any positive influence on the customer (Walter and Edvardsson, 2012). Previous findings proved that customers felt turned out by the restaurant due to the loud music played by the management.

Furthermore, the colors elements also play role and give different effect to the ambiance and customers. In an interview during the research by Watler and Edvardsson (2012), the participants commented that too much white color in the interior design made them feel uncomfortable and unwelcome. The couple said that "there was too much white and it felt quite sterile and cold with no cozy feeling and far too open. The ceiling was high and surrounding it was like too white, the atmosphere did not feel good. It was not relaxing and we did not feel quite welcome" (Watler and Edvardsson, 2012, p.112). Therefore, it is clear that ambiance is very important for a themed restaurant as it can influence the customer's mood.

\section{Lighting}

Based on the concept developed by Ryu and Jang (2008), one of the focused aspects of ambiance is lighting. It is claimed to be as particularly most important element, agreed by both Baraban and Durocher (2001) and Ryu and Han (2011). The researchers mutually understand that if the lighting in a restaurant goes wrong, it can affect all of the other elements. Different level of lighting is suitable for different types of restaurant and it is crucial to apply the appropriate lighting to enhance customer satisfaction. Ryu and Han (2011) did conclude that the low level of lights gives a higher level of comfort while comfort decreased as levels of light rose. In contrast, their findings pointed that bright lighting is associated with quick service and low prices, while warm lighting means a full service and high prices.

\section{Table Setting}

The table setting is the table that is "designed to present a prestigious image such as highquality flatware, glassware and the linen are effective tools for this image" (Ilgaz, Berrin and Ceren, 
2018 , p.8). Besides that, it is also referring to as the way that a table is set out and decorated for the preparation of a meal. Apparently, the table setting is an important issue in the restaurant and should be designed to present a particular and honored image. For example, high-quality flatware and glassware with the linen are excellent tools to portray a luxurious. Furthermore, the table setting also influences the customers cognitively and emotionally (Ryu and Han, 2011). These small items or utensil such as types of plates, glassware and types of tablecloth does matter in completing the overall environment in themed restaurant as explained by Ishak, Crang and Karim (2017). The small centerpiece on the middle of each table such as a vase of flowers or a candle can give the customer pleasure and relaxation feelings.

\section{Layout}

The layout is the design of objects such as machines or furniture in a space that eases the functional needs, give pleasure and comfort (Ryu and Jang, 2008). Lin (2004) said that the places of the table in a restaurant have a substantial effect on customer's experience other than giving a positive emotion (Liu and Jang, 2009). The right table and furniture layout in a themed-restaurant not only provide a positive emotion but also eases the movement of the staff to serve the food. Besides that, the distance of the table between each other also contributes to the good dining experience of the customer. As Lin (2004) claimed that, a proper table placement can give a sense of privacy and act as a boundary between customers. This is because most of the customer does not prefer a closer table to another customer because they can overhear their conversation hence interfering with the privacy that they seek. Privacy is the key here.

\section{Service Staff}

Ryu and Jang (2008) noted that service staff is the employee in an establishment and relate to the appearance, the number and the gender of the employees. Service staff is one of the essential factors as it not only affects customer satisfaction but also may influence their revisit intention (Ladhari, Brun and Morales, 2008; Lin and Mattila, 2010). The service staff includes the professionalism and most importantly is the willingness of the staff to help the customer that comes in any way possible. This will then make the customer feel welcome and please during their visit to the restaurant. However, Heung and Gu (2012) argued that it is not suitable to include staff as one of the elements in the physical environment because it is not a controllable factor like other elements such as ambiance and lighting. But, Dong and Siu (2013) indicated that the customers will be happy during dining if employees are attractive, polite, and willing to help them also give them special attention. For themed restaurant, the environment will be extra meaningful if the staff attire related close to the theme portrays.

\section{Methodology}

This research employed qualitative study to explore further the authentic dining experience in themed restaurant. According to Austin (2015), qualitative research helps researchers to access the thoughts and feelings of the participant then understand the meaning that they described from their experiences. The qualitative design also more related to the features, attributes and characteristics of a phenomenon that can be interpreted thematically. As this research investigated 
INTERNATIONAL JOURNAL OF ACADEMIC RESEARCH IN BUSINESS AND SOCIAL SCIENCES

Vol. 10, No. 3, March, 2020, E-ISSN: 2222-6990 C 2020 HRMARS

the authenticity of the dining experience in themed restaurant, the phenomenology approach has been used.

Data was collected through in-depth interviews with 10 informants who were the customers of themed restaurants in Klang Valley area. Despite no definite number of participants needed for particular qualitative research, Creswell (1998) suggested 5 to 25 participants, while Morse (1994) suggested at least 6 participants are enough for the phenomenological studies. These recommendations are just for the guidance; however, the researcher can stop collecting data when the saturation is reached. Photographic evidence was also documented to support the findings.

All interviews were audio-recorded with the interviewee permission and their identity will be kept anonymous. The recordings then transcribed and analyzed by using the thematic analysis using Atlas.ti software.

\section{Results and Discussion}

a. Staging the authentic dining experience

The result shows that there are various elements that contributed to the authentic dining experience in this type of restaurant. These elements had been grouped and classified into three respective main elements, which are the aesthetic facility, satisfying ambiance and attentive staff. These elements are the unique elements which give the strength to the themed restaurant in staging such ambiance.

Aesthetic Facility

The unique architectural design of a themed restaurant gives an enjoyable moment and memorable experience to the customers. It is crucial as the design of the building can devote a positive first impression of the overall concept to the customer (Hwang and Ok, 2013).

"What I can see here at Cartel is the mafia concept which is different from other restaurants. It is different because they build up this restaurant from the shipping container to portray the mafia concept." (IV1)

The present findings of the decoration seem to be consistent with the previous research by Walter and Edvardsson (2012) who found that, it can help the customers to imagine being in places or countries even that is unknown to them and create a sense of travel.

"The things I like the most are the wall decorations. It felt like I enter the school laboratory. The themed restaurant decorated the wall with a periodic table and also drawings of art related to science. Near the entry door, it had decorated with laboratory equipment and apparatus." (IV3) 


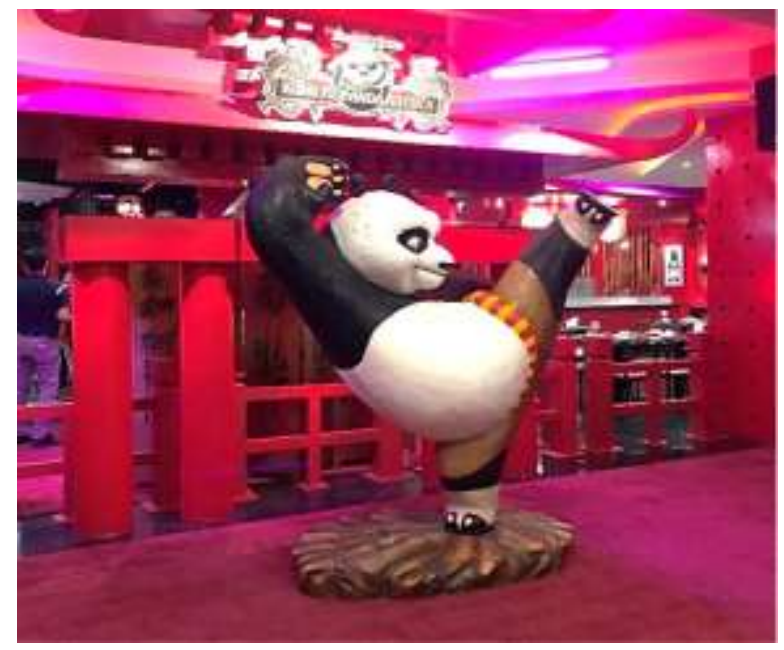

As Ishak, Crang and Karim (2017) defined props as the small decorative items that were selected to theming the overall environment, Walter and Edvardsson (2012) said that the theme delivered and decorations displayed in the restaurant is essential to help the customer remember every detail of the environment when they leave the restaurant. Figure 1 shows a big statue of Kungfu Panda at the entrance of Kungfu Panda themed restaurant that captures the customer's attention upon visiting the dining place.

\section{Figure 1 A gigantic statue captures the customer's attention}

\section{Comforting Ambiance}

A matching music background related to the theme of the restaurant will have a good impact on the overall customer's dining experience. The volume of the music background can help the customer to find relaxation inside the restaurant. The results obtained were in line with previous research by Ishak, Crang and Karim (2017) that stated music is something that can be controlled and influenced the ambiance of the restaurant.

"There is music but just for the background. So it is very chill. Not disturbing. They also have a live band here but just to entertain the customer while they are eating. The music is not hard music, they usually play acoustic songs." (IV1)

\section{Attentive Staff}

Dong and Siu (2013) indicated that the customers would be happy during dining if employees are attractive, polite, and willing to help while giving them special attention. Besides, the social interactions between customers and employees do affect the overall atmosphere (Nilsson and Ballantyne, 2014). These findings also in agreement with Chang (2016), who affirmed that perceived servicescape, such as the interaction between the employees and customers, influences the customers' emotions.

"Their service staff is the best. Here, if we want to celebrate a birthday they will play us a song. And also there is an upper level that they will play a live band. And they can arrange it for us if we want to celebrate a birthday or request a song." (IV1)

\section{b. Vulnerable Dining Experience}

Some of the weaknesses of the themed restaurant were discovered in the interview sessions. Even most of the informants claimed that they experienced excellent dining more than poor dining at the themed restaurant, there were still certain things that themed restaurant needs to be improved. The findings of the weaknesses have been strengthening with the photographic data that 
were obtained during the visit to the selected themed restaurant. The crucial weaknesses in themed restaurant are inadequate restaurant maintenance, the contradiction of expectation with realities and the pricy menu items. These elements and factors are vulnerable to the staging of authentic dining experience in themed restaurants and need to be carefully examined by the restauranteurs.

Inadequate Restaurant Maintenance

Ryu and Han (2011) emphasized that lighting is one of the strongest physical stimuli in restaurants, particularly in upscale restaurants. Therefore, if the restaurant owner put less attention to these attributes, it can lead to poor dining experience towards the customer.

"There's a few theme restaurants that I went, the lighting sources were not as good. I mean, we cannot, we just barely able to see our food. At least, just maybe enhance the light so that you can see your food. It is not like we are eating in the dark." (IV4)

"Denali open from evening until late at night. So for Denali, what the best thing here is only during the night because it is a rooftop restaurant. If we go during the day, it is quite hot." (IV1)

During the fieldwork, there were some light sources that burnt out and not repair due to its high cost. This type of deficiency can go wrong in giving a full satisfaction towards the consumers' consumption journey. Figure 4 and Figure 5 below show that the burnt lamp and bulb are not been replaced and this may affect the dining experience of the customer. The lack of maintenance in the lighting here will not turned out good in the pictures taken by the customers and they may not be satisfied with it.



Figure 2 The burnt out bulb that was not replaced

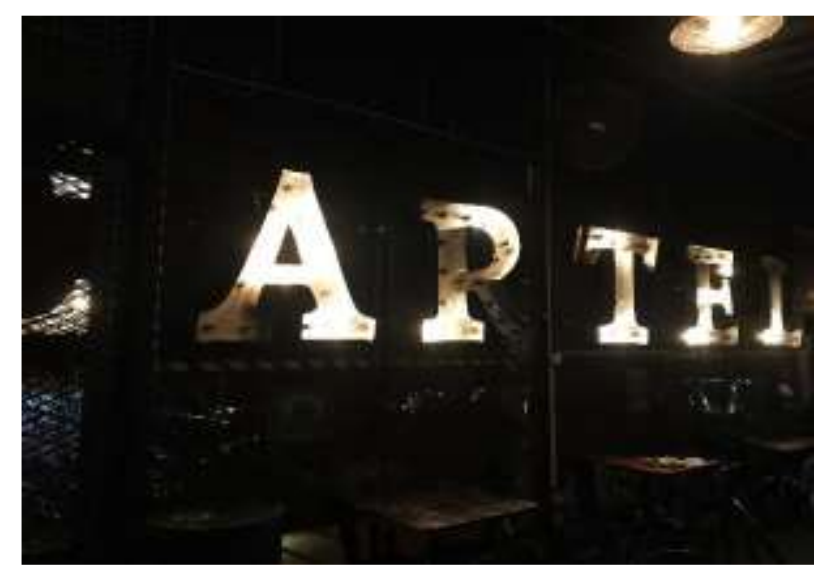

Figure 3 Several bulbs that left unrepaired

For the restaurant space, a narrowed spatial layout may have a direct effect on customer quality perceptions, excitement levels, and indirectly on revisit intention (Ryu and Han 2011). On the contrary, a large unoccupied space also gives effects on the excitement level of the customer. Based on the observation made through the fieldwork, a large unoccupied space created an empty feeling 
INTERNATIONAL JOURNAL OF ACADEMIC RESEARCH IN BUSINESS AND SOCIAL SCIENCES Vol. 10, No. 3, March, 2020, E-ISSN: 2222-6990 @ 2020 HRMARS

and make the customer think that the restaurant is not open for business. Figure 6 below showed that the restaurant has several sections that are not occupied hence creating an 'empty' vibe towards the overall environment.
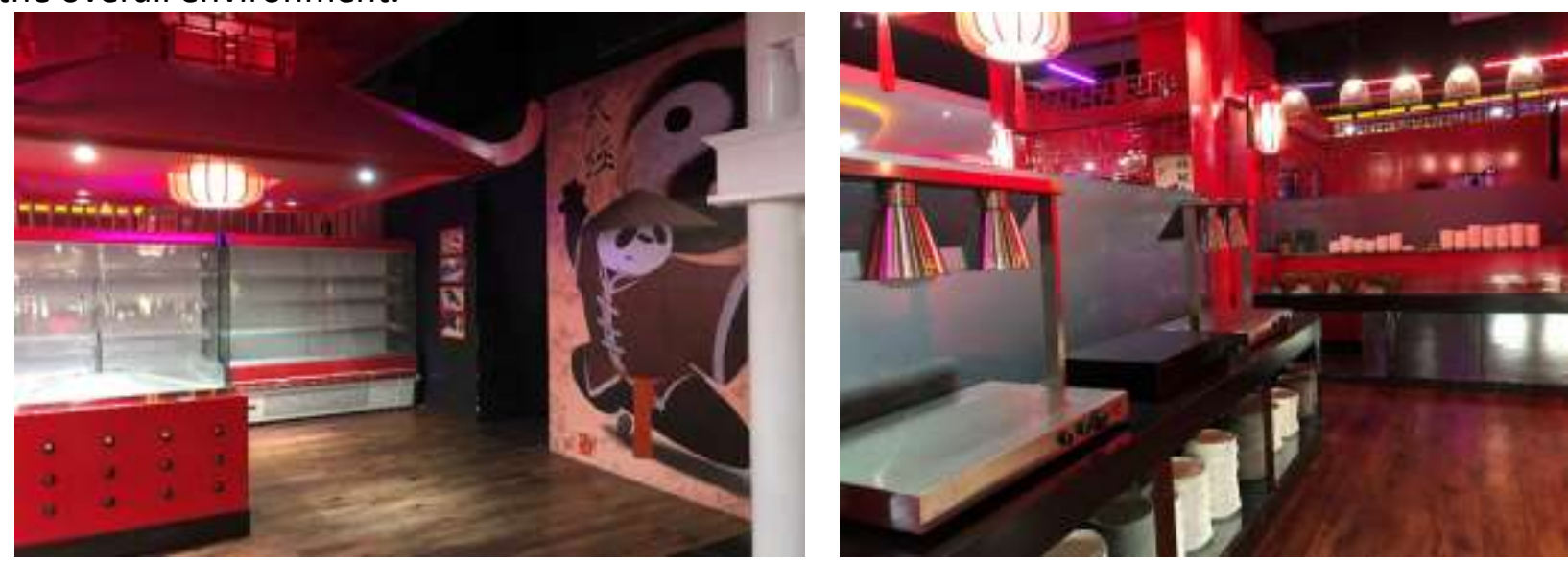

Figure 4 Some of an empty and unused sections in themed restaurant

The contradiction of Expectation with Reality

Informants stressed that they had experienced poor dining in themed restaurant in terms of the food presentation which is not as their expectation. This kind of situation is quite common and can happened as food quality is the elements in the restaurant that could not be able to predict before being experienced (Ilgaz, Berrin and Ceren, 2018).

"Usually the food. Basically that we suffer mostly in Malaysia is the food. People said it as all that glitters is not gold. It does not look like in the picture. This happened actually because there is no one to supervise the quality of café food in Malaysia." (IV2)

"Poor dining. For me poor dining may be in terms of food. For example the burger. I once got the uncooked burger patty." (IV6)

"Poor experience maybe when we saw the review, all good things. But when it comes to us, it does not reach our expectations." (IV7)

According to Jangga et al. (2012), customers measure the aspects related to both the food and the service received to decide whether their expectations have been met.

Pricy Menu Items

One of the findings of this study is parallel with the previous research by Ryu and Han (2011). The authors noted that a reasonable price can also provide customers' satisfaction as "menu pricing is a tangible nonfood-related attribute that is often used to communicate restaurant quality" (Ponnam and Balaji, 2013, pg. 48). Menu items in themed restaurant usually charged with medium to high prices however, many customers found that as long as the service and the food is worth the money spent, then they definitely will pay for it. 
INTERNATIONAL JOURNAL OF ACADEMIC RESEARCH IN BUSINESS AND SOCIAL SCIENCES

Vol. 10, No. 3, March, 2020, E-ISSN: 2222-6990 @ 2020 HRMARS

"I think the price is quite pricy for that portion of the food." (IV 3 )

"The price of the food in this restaurant is quite expensive. But suitable with the food portion. For example, I eat lamb chop which is RM29 but the portion is big. You can get two pieces of lamb." (IV1)

"I do not mind about the price. If you want to price it RM800, I am okay with it as long as I can get a good food experience from it." (IV2)

\section{Conclusion}

As a conclusion, the main goal of the study was to explore the authentic dining experience in themed restaurant. This goal has been achieved through two objectives which are determining the uniqueness of themed restaurant that leads to the authentic dining experience and exploring the weaknesses in themed restaurant that contribute to poor dining experience.

The exploration of the uniqueness of themed restaurant shows three main elements that can contribute to the authentic dining experience, which are the aesthetic facility, comforting ambiance, and attentive service staff. All of these elements play a significant role in themed restaurant to stage better dining to the customer as compared to a common casual dining place. If the restaurateur of themed restaurant knows how to focus on these elements, they will be able to engage their regular customer and might as well increase the new customers to visit their restaurant.

The second major findings were discovering the weaknesses in themed restaurant that contribute to the poor dining experience. The result of this investigation shows that among the vulnerable elements are inadequate restaurant maintenance, the contradiction of expectation with reality and pricy menu lead to the unpleasant dining experience at themed restaurants.

The restaurant managers should be aware of the restaurant maintenance so that the customer's satisfaction can be kept at the highest level. At the same time, the quality of food served also is very important and should be at its best so that it can meet with the customer's expectation and a worthy price of menu items also will always a favors for every customer.

\section{Significance of the Study}

Theoretically, this research extends the knowledge of themed restaurant and will fill the literature gap to help the future researchers to explore more about themed restaurant. Practically, this study will help the existing and new restaurateurs to improve their services in offering a unique dining experience which will satisfy customers' needs and wants. Therefore, dining will be more enjoyable with less risk of unpleasable experience hence increase the chance of revisit from the customer.

\section{Acknowledgement}

The authors wish to thank Universiti Putra Malaysia for the financial support under the Putra Young Initiative Grant (GP-IPM) [Vote no: 9673900]. 
INTERNATIONAL JOURNAL OF ACADEMIC RESEARCH IN BUSINESS AND SOCIAL SCIENCES

Vol. 10, No. 3, March, 2020, E-ISSN: 2222-6990 @ 2020 HRMARS

\section{References}

Ali, F., Kim, W. G., \& Ryu, K. (2016). The Effect of Physical Environment on Passenger Delight and Satisfaction: Moderating Effect of National Identity, Tourism Management, 57, 213-224.

Austin, S. (2015). Qualitative Research: Data Collection, Analysis, and Management. The Canadian Journal of Hospital Pharmacy, 226-231.

Baker, J. (1987). The role of the environment in marketing services, in: Czepeial, J.A., Congram, C.A., Shananhan, J. (Eds.), The Services Challenges: Integrating for Competitive Advantage, Chicago: American Marketing Association, 79-84.

Baraban, R. S., \& Durocher, J. F. (2001). Successful restaurant design. New York: John Wiley.

Beardsworth, A., \& Bryman, A. (1999). Late modernity and the dynamics of quasification: The case of the themed restaurant. The Sociological Review, 47 (2), 228-257.

Bitner, M. J. (1992). Servicescapes: The Impact of Physical Surroundings on Customer and Employees. Journal of Marketing, 56(2), 57-71.

Chang, K. C. (2016). Effect of servicescape on customer behavioral intentions: Moderating roles of service climate and employee engagement. International Journal of Hospitality Management, $53,116-128$.

Creswell, J. W. (1998). Qualitative Inquiry And Research Design: Choosing Among Five Traditions. Thousand Oaks, CA: Sage Publications.

Dong, P., \& Siu, Y. M. (2013). Servicescape elements, customer predispositions and service experience: the case of theme park visitors, Tourism Management, 36(3), 541-551.

Han, H., \& Jeong, C. (2013). Multi-dimensions of patrons' emotional experiences in upscale restaurants and their role in loyalty formation: Emotion scale improvement. International Journal of Hospitality Management. 32(1), 59-7

Heung, V., \& Gu, T. (2012) Influence of restaurant atmospherics on patron satisfaction and behavioral intentions, International Journal of Hospitality Management, 31(4), 1167-1177.

Hwang, J., \& Lyu, S. O. (2015), The antecedents and consequences of well-being perception: an application of the experience economy to golf tournament tourists, Journal of Destination Marketing \& Management, 4(4), 248-257.

Hwang, J., \& Ok, C. (2013), The antecedents and consequence of consumer attitudes toward restaurant brands: a comparative study between casual and fine dining restaurants, International Journal of Hospitality Management, 32, pp. 121-131.

Ilgaz, T., Berrin, G., \& Ceren, I. (2018). Dinescape Factors Affecting the Satisfaction and Loyalty of Fish Restaurant Customers. Journal of Tourism and Gastronomy Studies, 6, 4-22.

Ishak, F. A. C., Crang, P., \& Karim, M. S. (2017). Material management in themed restaurants: Inspiring the experience economy. Journal of Tourism, Hospitality \& Culinary Arts, 9(2), 493-504.

Kim, H., Woo, E., \& Uysal, M. (2015). Tourism experience and quality of life among elderly tourists. Tourism Management, 46, 465-476.

King, L. A., Richards, J. H., \& Stemmerich, E. (1998). Daily goals, life goals, and worstfears: Means, ends, and subjective well-being, Journal of Personality, 66 (5), 713-744.

Ladhari, R., Brun, I., \& Morales, M. (2008). Determinants of dining satisfaction and post-dining behavioral intentions. International Journal of Hospitality Management, 27(4), 568-573

Lin, I. Y. (2004). Evaluating a Servicescape: The Effect of Cognition and Emotion. International Journal of Hospitality Management, 23(2), 163-178. 
INTERNATIONAL JOURNAL OF ACADEMIC RESEARCH IN BUSINESS AND SOCIAL SCIENCES

Vol. 10, No. 3, March, 2020, E-ISSN: 2222-6990 C 2020 HRMARS

Lin, I. Y., Mattila, A. S. (2010). Restaurant servicescape, service encounter, andperceived congruency on customers' emotions and satisfaction. Journal of Hospitality Marketing Management, 19(8), 819-841.

Liu, Y., \& Jang, S. S. (2009). The Effects of Dining Atmospherics: An Extended Mehrabian-Russell Model. International Journal of Hospitality Management, 28, 494-503.

Liu, P., \& Tse, E. C. Y. (2018). Exploring factors on customers' restaurant choice: an analysis of restaurant attributes. British Food Journal, 120(10), 2289-2303. https://doi.org/10.1108/BFJ-102017-0561

Mehrabian, A., \& Russell, J. A. (1974). An approach to environmental psychology (pp. 216-217). USA: The Massachusetts Institute of Technology

Morse, J. M. (1994). Designing funded qualitative research. In Denizin, N. K. \& Lincoln, Y. S., Handbook of qualitative research (2nd Ed). Thousand Oaks, CA: Sage.

Namkung, Y., \& Jang, S. S. (2008). Are Highly Satisfied Restaurant Customers Really Different? A Quality Perception Perspective. International Journal of Contemporary Hospitality Management, 20(2), 142-155.

Nilsson, E., \& Ballantyne, D. (2014). Reexamining the place of servicescape in marketing: A servicedominant logic perspective. Journal of Services Marketing, 28(5), 374-379.

Ponnam, A., \& Balaji, M. S. (2014). International Journal of Hospitality Management Matching visitation-motives and restaurant attributes in casual dining restaurants. International Journal of Hospitality Management, 37, 47-57. https://doi.org/10.1016/j.ijhm.2013.10.004

Ryu, K. (2005). DINESCAPE, emotions, and behavioral intentions in upscale restaurants. Unpublished doctoral dissertation, Kansas State University, Manhattan, KS.

Ryu, K., \& Han, H. (2011). New or repeat customers: How does physical environment influenctheir restaurant experience? International Journal of Hospitality Management, 30(3), 599-611. https://doi.org/10.1016/j.ijhm.2010.11.004

Ryu, K., \& Jang, S. S. (2008). DINESCAPE: A Scale for Customers' Perception of Dining Environments. Journal of Foodservice Business Research. 11(1), 2-22.

Taylor, C. (1991). The ethics of authenticity. Harvard University Press, Cambridge, MA.

Tsai, C. T., and Lu, P. H. (2012). Authentic dining experiences in ethnic theme restaurants, International Journal of Hospitality Management, 31 (1), 304-306.

Wood, N. T., \& Munoz, C. L. (2007). No rules, just right' or is it? The role of themed restaurants as cultural ambassadors. Tourism and Hospitality Research, 7(3/4), 242-255.

Walter, U., \& Edvardsson. (2012). The physical environment as a driver of customers service experiences at restaurants. International Journal of Quality and Service Sciences, 4(2), 104-119.

Whitaker. (2010). Wordpress. Retrieved from Restaurant-ing through history: https://restaurantingthroughhistory.com/2010/04/01/birth-of-the-theme-restaurant/ 